\title{
COVID-19 in Spain and the Use of Geospatial
} Information

\author{
Carmen Femenia-Ribera and Gaspar Mora-Navarro
}

Spain declared a state of emergency on 14 March because of the serious situation due to COVID-19. Three months later there were more than 27,000 confirmed deaths due to the virus. During this period there were many initiatives using geospatial information to predict, follow, and detect infections, as well as control mobility. These measures were implemented by the central government, as well as regional governments and local councils. Most of these geospatial applications use open-access geospatial information that reuse public sector information and add value to this data. In this way, open data supports decision-making by the administration. Numerous thematic maps, spatial analyses, geoportals, websites, and mobile applications have recently appeared; and never have so many boundary maps have been published in the Spanish media. Geospatial information in Spain is likely to continue playing an important role as the pandemic evolves, and greater resilience is needed to address this and future challenges.

\subsection{COVID-19 and the State of Emergency in Spain}

Spain has been a member of the European Union since 1986 and is located in the southwest corner of Europe. The nation has an area of $505,944 \mathrm{~km}^{2}, 4,964 \mathrm{~km}$ of coastline, and a population of 46.5 million. Spain has the world's $15^{\text {th }}$ largest economy (2019) in terms of gross domestic product according to the International Monetary Fund, and is the world's second most popular nation for tourist visits (2018) according to the World Tourism Organization.

Spain has a central government, 17 regional governments, and 2 largely self-governing cities on the Mediterranean coast in Africa. The nation is also divided into 50 provinces and there are 8,125 local councils.

For geographical information, the main national organisation is the National Geographic Institute (IGN) ("Instituto Geográfico Nacional, IGN," [1]). All of the national territory is mapped in digital format. Spain also has orthophotographs of the entire nation as part of the Aerial Photography National Plan (PNOA) ("Plan Nacional de Ortofotografía Aérea, PNOA," [2]). The Spanish Spatial Data Infrastructure (IDEE) ("Infraestructura de Datos Espaciales de España, IDEE," [3]) centralises the geographical information of the regional governments and local administrations in line with the European INSPIRE Directive. The regions also have their own cartographical institutes. Cadastral maps are made freely available through the Electronic Office of Cadastre (SEC) ("Sede Electrónica del Catastro, SEC," [4]) of the Directorate General for Cadastre (DGC) ("Dirección General del Catastro, DGC," [5]), as part of open data policies, and policies for the reuse of Spanish public sector information. 
Spain was the country most affected by Covid-19 after China and Italy. The virus started to be noticed early in February, with the first cases in the Canary Islands towards the end of January. A state of emergency was declared on 14 March. At that moment, the central government assumed all relevant powers and residents were quarantined in their homes. On 14 March the number of infected people was 5,753, and there were already 136 deaths, according to the health ministry. Just three months later, on 14 June, the total number of notified cases was 244,109 and there had been 27,136 deaths. Madrid and Barcelona were the worst affected cities. Forty new cases of infections were notified on the last day of nationwide quarantine (14/6/2020) with 25 deaths in that week. At that moment, the virus was considered controlled in Spain, with only small localised infections remaining. The highest point of the infection curve was at the end of March and the beginning of April. On 1 April there were 930 deaths ("Enfermedad por nuevo coronavirus, COVID-19," [6]).

The state of emergency lasted just over three months (from 14 March to 21 June). At the end of the state of emergency, the central government returned powers to the regional governments. During this period, a four-stage plan for a transition to a new normality was introduced. Each stage lasted about two weeks. During these stages mobility was controlled to avoid the spread of the virus, and the borders between counties, regions, provinces, and local councils become very important - together with the associated geographical information ("Estado de alarma y Nueva normalidad. Medidas crisis sanitaria COVID-19," [7]).

\subsection{Geospatial Information Use}

Geospatial information has been fundamental from the first signals of infection. The regions sent daily numbers for infections, deaths, and recoveries for each province. That information could be seen on choropleth maps.

This type of map was also frequently used in the transition to a new normality, where the stage for each province was indicated. Each stage depended on the provincial sanitary conditions, and each stage meant different mobility restrictions. At the beginning, the areas of control were the individual hospital authority areas, but this idea was abandoned because it was too difficult for the police to control inter-regional mobility as the exact hospital areas boundaries were not well known.

The Spanish provinces were then used as the basic units for controlling mobility. However, the municipality boundaries were also used in stage 0 (started on 2 May). In stage 0 , mobility was only allowed inside each municipality. People were allowed a daily walk within a one-kilometre radius from their homes. Numerous mobile applications showed a circle with a one-kilometre radius centred on the user's home. These applications were launched by both public and private organisations [8].

Many tools appeared that used geographical information to control mobility after quarantine, as well as track the contacts of infected people. These applications included mobile applications, geoportals, thematic maps (choropleths, point, heat maps, and so on); and were used at national, regional, and local levels. Many of these applications employed free and official open access digital map data.

Due to the seriousness of the pandemic, and the enormous importance of spatial data infrastructures in the management of the crisis, it was considered necessary to allow access for all resources that could be useful in fighting the pandemic. At a national level, there is a collection of open resources on Covid-19 in the IDEE website. In this collection, there is an index list of data published by international, national, and local administrations ("Infraestructura de Datos Espaciales de España, IDEE. Recursos abiertos sobre la COVID-19," [3]).

This information is mainly organised by regions. The geoportal of the Spanish Terrestrial Transport General Directorate shows maps of tourist accommodation, restaurants, shops, rest areas, and take-away restaurants near to main roads - all of which have been obliged to remain open. These maps facilitated the location of supplies for workforces and enabled the main national services to remain supplied ("Punto de Información de servicios de restauración," [9]). The Ministry for Ecological Transition and Demographic Challenge also published a map with open petrol stations. 
Figure 44.1 shows an example of a regional COVID-19 geoportal. The geoportal monitors the pandemic situation in the region of Valencia. The geoportal has been developed by the Valencian Cartographic Institute (ICV) ("Institut Cartogràfic Valencià, ICV," [10]), using ESRI technology and open data from the regional health authority [11]. It shows the spatial distribution of the pandemic and information is updated daily. It was started on 11 April and initially showed the 24 sanitary boundaries within the region. Municipal boundaries were not initially included to avoid stigmatising any towns or cities. This information was later included when the pandemic came under more control.

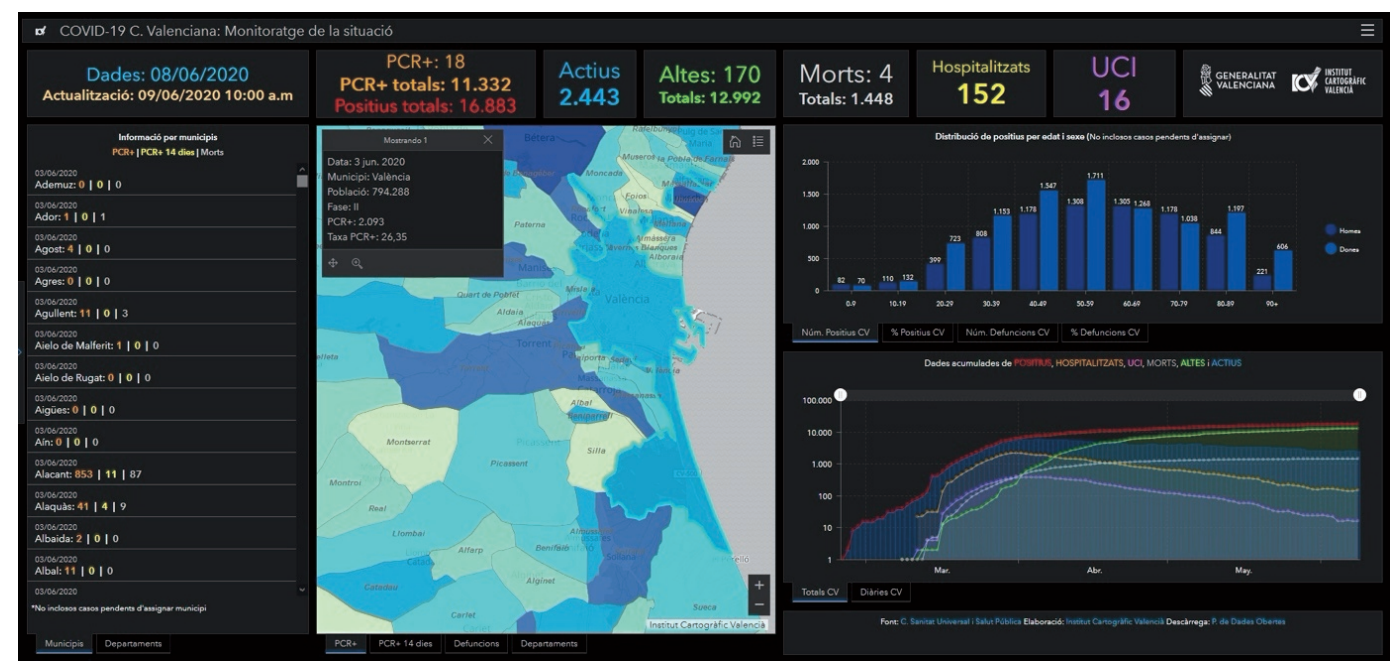

\section{FIGURE 44.1}

Geoportal to Monitor the Pandemic in the Valencia Region. Source: [11]

Some cadastral offices worked with regional governments to map the location of strategic facilities such as public sport centres or schools.

Eurostat (the Statistical Office of the European Union) performed a spatial analysis to detect risk areas, using population data, combined with the European healthcare services dataset [12], transport networks, and cadastre addresses.

Universities performed spatial analyses to calculate, for example, the most vulnerable provinces (using the population density, risk population indices, and especially the layer of interest points, like hospitals, pharmacies, and supermarkets). Universities also made a predictive analyses.

There have also been many relevant mobile applications developed in both the private and public sectors, as well as by universities. Most of these applications use GNSS and the objective is mainly to help people to avoid crowds. The usefulness of these applications is conditioned by the number of users who install them and share their locations. Councils have developed applications to control access to public spaces and facilities, as well as beaches and pools. Some use drones and image analysis to automatically count people in open spaces. The main goal is to ensure the safety of tourists who mostly come to Spain looking for sunshine and sand. Private companies are developing these types of application and selling them to public administrations.

Telecommunication companies exceptionally made their customer mobility data available to the central government to control infections, despite the geolocation of user mobiles phones colliding with privacy policies. Currently there is an ongoing discussion about privacy rights in the Data Protection European Commission. 


\subsection{Conclusions}

- Never before have so many boundaries maps been published in the Spanish media.

- Free and open access to geospatial data enables the development of many applications in private as well in public sectors - emphasising the value of geospatial data.

- Many ministries manage spatial information: including industry, health, transport, mobility, and ecological transition.

- Standardised geospatial information in the European framework enables spatial analysis using big data.

- User geolocation obtained from smartphones causes privacy problems that must be examined and clarified.

- Thematic maps, spatial analysis, geoportals, big data, GNSS, and drones are words linked to geospatial information that have frequently appeared in the media during this crisis.

- Geospatial data enables predictive analysis, tracking infected people, and statistical studies that support decision making by public administrations.

- Geospatial information in Spain is likely to continue playing an important role as the pandemic evolves.

- Updated and quality geospatial information is necessary to improve community resilience and respond to possible outbreaks and future crises.

\section{References}

[1] Instituto Geográfico Nacional (IGN). 2020. URL https://www.ign.es.

[2] Plan Nacional de Ortofotografía Aérea (PNOA). 2020. URL https://pnoa.ign.es/.

[3] Infraestructura de Datos Espaciales de España (IDEE). Recursos abiertos sobre la COVID-19. 2020. URL https://www.idee.es/web/guest/recursos-covid-19.

[4] Sede Electrónica del Catastro (SEC). 2020. URL http://www.sedecatastro.gob.es.

[5] Dirección General del Catastro (DGC). 2020. URL http://www.catastro.minhafp.es.

[6] COVID-19 Enfermedad por nuevo coronavirus. 2020. URL https://www.mscbs.gob.es/profesionales/ saludPublica/ccayes/alertasActual/nCov-China/home.htm.

[7] Estado de alarma y Nueva normalidad. Medidas crisis sanitaria COVID-19. 2020. URL https:// administracion.gob.es/pag_Home/atencionCiudadana/Nueva-normalidad-crisis-sanitaria.html\#. XxWEOedS-Uk.

[8] IGN. Aplicación IGN conocer área radio $1 \mathrm{~km}$. 2020. URL https://www.ign.es/resources/viewer/ calculadora $1 \mathrm{~km} . \mathrm{html}$.

[9] Punto de Información de servicios de restauración. 2020. URL https://portalweb.fomento.es/ VisorGeograficoDGTT/Inf ormacionRestauracion.

[10] Punto de Información de servicios de restauraciónInstitut Cartogràfic Valencià (ICV). 2020. URL http: //www.icv.gva.es/es.

[11] ICV. COVID-19 C. Valenciana: Monitoratge de la situació. 2020. URL https://experience.arcgis.com/ experience/42474fe756ee4714b7d8fbb730134b92.

[12] Eurostat. Mapping healthcare services. 2020. URL https://ec.europa.eu/eurostat/web/products-eurostatnews/- /WDN-20200415-1 ? inheritRedirect=true\&redirect=\%2Feurostat $\% 2 \mathrm{Fweb} \% 2 \mathrm{Fcovid}-19 \% 2 \mathrm{Fpopulation}$-health. 